УдК 327(510)"1955"(093.2)

$327(510: 73) " 1955^{\prime \prime}(093.2)$

327(510:47)"1955"(093.2)

Оригиналан научни рад

Примљен: 26.11. 2015.

Прихваћен:14. 2. 2016.

He YANQING

Institute for China Studies

University of Malaya

\title{
The Implementation of the Sino-U.S. Ambassadorial Talks against the Background of the Geneva Summit 1955: PRC's Diplomatic Achievements with the Help of the Soviet Union
}

\begin{abstract}
This article uses the newly declassified archives of the Chinese Foreign Ministry, some other Chinese archival materials and some declassified archives of the United States to reexamine the process of implementing Sino-US ambassadorial talks and analyze the links between these talks and the four-power Geneva Summit in 1955, with particular attention dedicated to the mutual cooperation and mutual support between China and Soviet Union. In contrast to previous scholarship, this article believes that the Soviet Union exercised a more important role in the process of implementation of the Sino-US ambassadorial talks. This process was a perfect example of the "honeymoon" period of the Sino-Soviet relationship in the mid1950s. This article also discovers that some of the first cracks in the Sino-Soviet relationship also appeared during the golden years of the Sino-Soviet alliance.
\end{abstract}

Key words: Geneva Summit, Geneva spirit, Sino-US ambassadorial talks, Sino-Soviet relations

The very first summit of great powers after the Second World War, which was co-sponsored by the United States, the Soviet Union, the United Kingdom and France, was held on July 18-23 1955, in Geneva. 
The government of the People's Republic of China (PRC) held this summit in very high esteem. The following statement was made by Chinese officials: "The four-power Summit, following the Korean armistice conference in Geneva last year and this year's Asian-African Conference, once again proved that the resolution of international disputes could only come through negotiations. If every country could hold negotiations in a sincere spirit, and could work together through joint efforts, every international problem could be resolved in a gradual and smooth way". ${ }^{1}$ Later, this spirit of mutual cooperation was colloquially dubbed as the "Geneva spirit" by the PRC and the Soviet Union. Of course, the "Geneva spirit" came about under Soviet Union's vigorous advocacy and it meant peaceful negotiations between states living under different systems. A week after the closure of the Geneva Summit, China and the United States began to implement protracted and rather famous Sino-U.S. ambassadorial talks. ${ }^{2}$ At first, the location of these talks was also in Geneva. Did the Geneva Summit have any influence on the beginning of the series of ambassadorial talks between these two countries? How did China finally decide to sit at the table with the United States after the three-year war in Korea, PRC's bombardment of the off-shore islands in the Taiwan Straits, and a very long period of mutual hostilities? Did the implementation of Sino-US ambassadorial talks have any connection with the Soviet Union and its policies?

Research on the Sino-U.S. ambassadorial talks is not new in the fields of diplomatic history studies and political science. And a significant part of this research focused its attention on the following questions: the general role of these talks, ${ }^{3}$ the decision-making process in

1 This comes from Premier Chou En-lai's speech at the second session of the First National People's Representative Meeting on July 30, 1955. People's Daily, July 31, 1955.

2 On August 1, 1955, the People's Republic of China (PRC) and the United States started a series of ambassadorial-level talks in Geneva to discuss the repatriation of nationals and other issues of mutual concern. Because the two countries did not have formal diplomatic relations, these talks were the principle form of contact between them for sixteen years and 136 different meetings were held. According to the place of these talks, the whole series of talks could be divided into the Geneva Talks (lasting from 1955 to 1957) and the Warsaw Talks (lasting from 1958 to 1970). They ended when the U.S. President Richard Nixon visited China and set the stage for the eventual U.S. recognition of the People's Republic.

3 According to their different attitudes about the role of the talks, American researchers can be divided into two different fractions. Kenneth T. Young, who is probably the first American scholar who did research on the ambassadorial talks, is also one of the famous scholars in the positive-attitude fraction. He analyzed ten meetings of the Sino-US ambassadorial talks from September-November 1958. His attitude is 
the United States, ${ }^{4}$ the process of the talks and their characteristics. ${ }^{5}$ However, research and analysis of the decision-making process in

that these talks, which lasted 12 years, "proved to be worthwhile. This has played a useful role in easing tensions and controlling crises". Young further stressed that these ambassadorial talks provided for both sides the most important experiences before the reconciliation negotiations later. These negotiations were unique and paradoxical. And these talks slowly cultivated some kind of trust which was vital to the stability of the international situation. Kenneth T. Young, Negotiating with the Chinese Communists: The United States Experience, 1953-1957, (New York: McGrawHill, 1968). - Harry Harding and Appu K. Soman also affirmed that the ambassadorial talks have promoted the final normalization of Sino-American relationship. Harry Harding and Ming Yuan, Sino-American Relations, 1945-1955: A Joint Reassessment of a Critical Decade, (Wilmington, Delaware: Scholarly Resources, 1989); Appu K. Soman, Double-Edged Sword: Nuclear Diplomacy in Unequal Conflicts: The United States and China, 1950-1958, (Praeger, 2000). - Another fraction, represented by some of the historical participants in the Sino-American relations, such as Alexis Johnson, Jacob Beam and Henry Kissinger, was inclined to consider the talks as useless. Because there were few new concepts that these talks had put forward. Jacob Beam, Multiple Experience: An American Ambassador's Unique Perspective on East-West Issues, (New York: W.W. Norton 1978); Alexis Johnson, The Right Hand of Power: The Memoirs of an American Diplomacy, (Englewood Cliffs, N.J.: Prentice Hall, Inc., 1984). In China, most scholars regarded these talks as useful, same as was the official attitude of the PRC government which was embodied in: The Diplomatic History of PRC, 1949-1956,ed. by Pei Jianzhang, (Beijing: The World Knowledge Press, 1998) and The Diplomatic History of PRC, 1957-1969, ed. by Wang Taiping, (Beijing: The World Knowledge Press, 1998). They believed that the ambassadorial talks proved to be a unique channel of communication between the two sides which proved to be working. As one of the Chinese witnesses, Wang Bingnan, who was the Chief Representative of China in the nine-year-long Sino-U.S. ambassadorial talks, believed these talks were a form of special communication that proved to be more effective for contemporary relations than some other official diplomatic contacts. Wang Bingnan, Retrospect of the 9-year Talks between China and the US, (Beijing: The World Knowledge Press, 1985), 93.

4 Due to the possibility of easier access to the official archives, scholars have done a lot research on Washington's decision-making process. Besides the achievements as mentioned above, such as Kenneth T. Young's, a lot of other works are alsooutstanding. For example, Steven M. Goldstein's article: "Dialogue of the Deaf? The Sino-American Ambassadorial-Level Talks, 1955-1970", Re-examining the Cold War: US-China Diplomacy, 1954-1973, Collected in Robert Ross \& Jiang Changbin eds, (Cambridge: Harvard University Press, 2001), 200-237; Yafeng Xia's article: "Negotiating at Cross-Purposes: Sino-American Ambassadorial Talks, 1961-1968", Diplomacy and Statecraft, 16:2, June 2005, 297-329 and his book: Negotiating with the Enemy: U.S.China Talks during the Cold War, 1949-1972, (Bloomington, IN: Indiana University Press, 2006); Dayong Niu's: Warsaw Ambassadorial-Level Talks between China and the United States, 1961-1963 (Historiography at the Peking University, 2000).

5 Although many scholars are interested in the Sino-American ambassadorial talks, most of them considered the Geneva talks as more worth studying, especially concerning the agreement on the citizens returning to their original countries and interactions regarding the Taiwan crisis in 1958. Besides that, the 135th and 136th Ambassadorial Talks in 1970 have also attracted much attention because they were preludes of the Sino-American rapprochement. 
China are still inadequate, generally due to the lack of Chinese government archives. ${ }^{6}$ As for the question about Soviet Union's influence on the process of decision-making in China, there is much less research.

In this article, the author will analyze the implementation process of the Sino-U.S. ambassadorial talks against the background of the Geneva Summit. This process was also an outstanding reflection of the real relationship existing between China and the Soviet Union in the mid1950s. Inside China, contemporary research in the field of Chinese diplomatic history studies has been divided into different fractions according to their different fields of interest: different countries. This kind of division is so deep that there are few cross achievements among the different fractions. Thus, there is also a vacuum zone in Chinese diplomatic history studies. The triangle relationship between China, the Soviet Union and the U.S. in 1955, also falls into that category. This article is going to explore this vacuum zone and it will try to give a new perspective to the Sino-Soviet and Sino-U.S. relations.

First of all, let us turn to the time before the implementation of Sino-U.S. ambassadorial talks. The direct contact between the governments of the People's Republic of China and the United States after the Korean War took place in the shadow of the Soviet Union. A year before, during the Geneva Conference on Korea and Indochina (April 26 - July 20 1954), the PRC government not only ascended on the international stage as a superpower for the first time, but also Beijing achieved certain results: it came into direct contact with the Americans. But the direct contact came through the Soviet side which passed on messages between the Chinese and U.S. delegations. According to the reminiscences of Wang Bingnan, ${ }^{7}$ who was in charge of internal affairs of the Chinese delega-

6 One of the main papers that aims at analyzing Beijing's decision-making process in the Sino-US ambassadorial talks is Zhang Baijia and Jia Qingguo's article: "The Steering Wheel, Shock Absorber and Surveying Instrument in Antagonism: SinoAmerican Ambassadorial Talks Seen from the Chinese Perspective", Contemporary China History Studies, Vol. 1, 2000. Zhang Baijia and Jia Qingguo mentioned in their article: "The Chinese leaders would like to ease their relations with the U.S., while improving their international position through the talks. After 1956, the Chinese government began to lose their higher expectation in ambassadorial talks; reversely they resorted to American civics, actively promoted 'the People's Diplomacy' between China and U.S. In the Warsaw talks, China utilized the ambassadorial talks as a microphone. At the end of 1960s, Chinese leaders intended to normalize the Sino-American relationship, so they utilized the ambassadorial talks as a political probe. Beijing changed its conception and treatment of the talks in different periods."

7 Wang Bing-nan was Secretary General of the Chinese Delegation at the Geneva Conference. And he was appointed as Chinese ambassador to Poland in March, 1955. At the ambassadorial post in Poland, he was concurrently the Chief Representative of China in the nine-year-long Sino-US ambassadorial talks. 
tion in Geneva, this was how things happened: "One day Molotov came to find our Prime Minister Zhou Enlai and told Zhou that he had invited the delegation of the United States to dinner before their Secretary of State John Foster Dulles arrived to Geneva. During this dinner, he had a personal conversation with the deputy head of the U.S. delegation Walter Bedell Smith and he had found out that Smith had a critical view on some policies of the U.S. government. According to Molotov's statement, Smith had an opinion that the hostile policies which the United States pursued towards the PRC were unrealistic". ${ }^{8}$ Inspired by this message, the Chinese delegation seized the opportunity to get in touch with Smith. At that moment, the United States government urgently requested the repatriation of American soldiers and civilians held inside Chinese borders. Therefore, Beijing government also called for direct contact between the two governments of China and U.S., not via third party. Although Washington worried about the prospect that direct contact with China could cause some misunderstanding inside the U.S. government concerning the policy of refusal to recognize the PRC government. However, the issue of returning the U.S. citizens home was so important that they could not refuse to hold talks with Beijing. It was agreed to talk to the Chinese under the sponsorship of the British charge d'affaires in Beijing Baron Trevelyan. From June 5 to 21 1954, Beijing and Washington conducted four talks at the consular level. Then, from July 16 to 211954 both sides sent liaisons and were in contact twice. After the end of 1954 Geneva Conference, regular contacts at the consular level had been realized and the first direct contact started on July 29, 1954. This kind of contact continued until July 1955. In order to avoid any misunderstandings concerning these contacts between Washington and Beijing, U.S. Sectary of State Dulles specifically pointed out in his telegram to the U.S. Embassy in the United Kingdom: "Arrangement for informal exchange information with Chinese Communists at subordinate Consular level in Geneva is merely an extension of the staff level conversations at the Geneva Conference on re-detained Americans. No negotiations or representations contemplated at Geneva. Geneva arrangements in no way intended to interfere with the British representation of American interests in Communist China." ${ }^{9}$ Even so, the PRC government had still made a "small hole" on the tightly closed door, a channel to observe Washington and make contact with it. Such a breakthrough happened under the influence of the Soviets, intentionally or not.

$8 \quad$ Wang Bingnan, Retrospect of the 9-year Talks between China and the U.S., 19.

9 Foreign Relations of the United States (FRUS), 1952-1954, Vol. 14, Washington: United States Government Printing Office, 1985, 515. 
After that, the Soviet Union continued to work closely with China and Moscow used various international forums to contribute to the direct talks between the governments of PRC and the U.S.

\section{The Preparation of the Geneva Summit and the Possibility of Sino-U.S. Ambassadorial Talks}

In the second half of 1954, just when the Soviet Union was actively preparing to participate in the coming Geneva summit, the First Taiwan Strait Crisis unexpectedly broke out. Therefore, the Soviet Union was preoccupied with crisis mediation. Soviets tried to seize the opportunity of this Summit to help the PRC carry out some of the appeals and get into direct touch with the U.S.

As for the Summit topics which the Soviet government had prepared, some of the Chinese's requirements were also included. At the end of 1954, the Moscow government sent the documents of the coming Geneva Summit to Beijing and solicited some of the Chinese views on them. On January 1, 1955 Chinese Foreign Ministry sent a formal reply to Moscow as "Our Answer to the Central Committee of CPSU about the Four-Nation Summit in Geneva". In this reply, the Chinese side expounded: "We fully agree with the position of the CPSU Central Committee and its basic expectation for the Summit". But according to their estimate, Chinese officials also said: "Even though the Americans are not prepared to solve any substantive issues at this summit, our sincere initiatives and active movements to ease the tension in the world would somewhat contribute to the success of the Summit. In the end, the meeting could achieve a certain degree of agreement". The only suggestion put forward by the PRC government was that "the Far Eastern problems should be considered as one of the important topics at the Geneva Summit". ${ }^{10}$

As for the Taiwan Strait issue, the PRC government agreed with the opinion of Moscow: "We agree with the CPSU Central Committee's view that it should contribute a lot to the realization of the Sino-U.S. direct talks, since that is the most likely way to achieve peaceful negotiations. As for the other ways, such as holding a special five-superpower summit to discuss the Taiwan issue and the Far Eastern problems, we also welcome that, but we look upon them as the indirect method which could be used in the right moment in time. In addition, we think that the beginning of direct negotiations between China and the U.S. could be implemented by the envoys of both countries that are stationed in Moscow, New Delhi

10 Chinese Foreign Ministry Archives (PRC FMA), Record ID: 111-00065-02. 
or London" ${ }^{11}$ As for the release of American pilots, which had been previously raised by the Soviet Union in its letter to CPC, the Chinese side also expressed full agreement with its content. Beijing's reply to Moscow was: "We agree with the views of the CPSU Central Committee concerning this problem. Sometime around the Geneva Summit, we are ready to reveal the news to the Indians that we will soon release the Americans".12

Thus, the PRC and the USSR shared the consistent and common interest with regards to the problem of lessening international tensions. They held necessary contacts and cooperated with regards to the issue of realization of Sino-U.S. direct talks. In addition, in order to create an atmosphere of détente between the East and the West, which could prove to be beneficial to the success of the Geneva Summit, the Soviet Union expressed its utmost interest in China's 'own' problem of releasing the captive American pilots, which was also an issue of the greatest importance for the United States.

As a key suggestion to incite the direct talks between China and America, a Ten-Nation Meeting which included the PRC, the U.S., the U.K., the USSR, France, India, Burma, Indonesia, Pakistan and Ceylon was proposed by Molotov in his statement about easing tensions in the Far East area on February 2, 1954. Beijing government immediately acknowledged the importance of Molotov's proposal, while Zhou Enlai expressed his opinion on the issue of tensions in Asia and the Taiwan Strait's problem to India's ambassador to China Nedyam Raghavan in the famous West Flower House of the Sea Palaces. That time Zhou said: "If there were an international meeting to discuss these problems, the United State would have to talk with Chinese face to face. And we will not refuse to talk with the Americans during such a meeting... Since it is the Americans who have caused such tensions in the Far East, it is not us China, therefore it is the Americans who really need to talk directly to China. We can talk during an international meeting, also joined by other countries. But now the Americans hide behind and incite Chiang Kai-shek's government to step forward and start negotiations with others. This is a plot to engage us into a two-China discussion on one hand, and put their responsibility on us on the other" ${ }^{13}$ In addition, the People's Daily continually published news about endorsements on the Ten-Nation Meeting proposed by Moscow coming from the governments and media of Indonesia, Romania, India

\footnotetext{
11 PRC FMA, Record ID: 111-00065-02.

12 Ibid.

13 The Diplomatic History Research Office of the PRC Ministry of Foreign Affairs, Zhou Enlai Diplomatic Activities Memorabilia, 1949-1975, (Beijing: The World Knowledge Press, 1993), 100.
} 
and Burma. ${ }^{14}$ But the Washington government had no interest in such an international meeting which excluded the Chiang Kai-shek government and eventually they refused to attend it.

As for the famous statement of Zhou Enlai at the Bandung Conference in which the Chinese government expressed its desire to "sit at the table and negotiate with the Americans" for the first time, Moscow immediately demonstrated its support and appreciation for China's proposals. Zhou's statement was issued on April 23, 1955, during the meeting of the heads of delegations of India, Pakistan, Burma, Sri Lanka, Thailand, Philippine, Indonesia and China. With regards to the Taiwan Strait Crises which was developing at that time, Zhou said: "Relations between the Chinese People and the American People are friendly. Chinese people are unwilling to fight with the United States. Chinese government is willing to negotiate with the United States. We can sit down and discuss the problems to lessen tensions in the Far East, especially in the Taiwan Strait Crisis". ${ }^{15}$ It was in this statement that Zhou Enlai officially expressed Beijing's approval of the Ten-Nation Meeting proposal of the Soviet Union. Zhou said: "With regards to the form of negotiations between China and the United States, the Chinese government believes that the proposal of the Soviet Union on the Ten-Nation Meeting is acceptable. But we are also willing to consider other forms of negotiations." ${ }^{16}$ Moscow also demonstrated its official support for China's attitude on Sino-U.S. direct talks. Later on, Moscow strongly emphasized that "the Soviet delegation will support comrade Zhou Enlai's proposal on April 23 concerning the direct talks between China and the United States". ${ }^{17}$ Such close interactions could show the depth of trust and corporation between Beijing and Moscow on the issues of lessening of tensions in the Taiwan Strait and implementing the agenda of the Sino-American direct talks.

But the attitude of the U.S. government toward direct talks with the PRC was negative. On April 26, 1955, three days after Zhou's statement in Bandung, Secretary of State Dulles made a statement during a press conference. Dulles did not deny the possibility of direct talk with Chinese, but he said: "Whether or not that was a sincere proposal remains to be seen. Perhaps the Chinese Communists were merely playing a propaganda game. But we intend to try to find out." However Dulles refused

\footnotetext{
14 People's Daily, February 16, 1955, 1; People's Daily, February 18, 1955, 1.

15 The Literature Research Center of the CPC Central Committee, Zhou Enlai Chronicle, 1949-1976, Vol. 1, (Beijing: The Central Literature Press, 1997), 470.

16 Zhou Enlai, "Report on the Asian-African Conference", The People's Daily, May 17, 1955.

17 PRC FMA, Record ID: 206-00061-07.
} 
to enter into any multilateral or bilateral discussions with the Chinese Communists without the presence of the Chinese Nationalists. He said, "We are not going to deal with the rights of the Chinese Nationalists, and their claims, in their absence." In addition, Dulles believed that the very "first thing" of such talks was to "find out whether there is a possibility of a cease-fire in the region". So Dulles regarded "a cease-fire as the indispensable prerequisite to anything further". 18

The Chinese government initially expressed intense criticism of the Dulles' statement, but sometime later, it took further steps to ease tensions and seek a peaceful settlement of the Taiwan Strait issue. As for Dulles' statement, Zhou Enlai insisted that "China is not at war with the United States, the cease-fire problem is completely irrelevant."19 And then he announced: "At any time, the Chinese government cannot accept that the Chiang Kai-shek clique participates in any international conference. There are only two possible ways for the Chinese people to liberate Taiwan: war and peace. If it is possible, the Chinese people are willing to use peaceful means." ${ }^{\prime 20}$ It seemed that there was no possibility for compromise on China's side. However, a few days later, there was a change expressed during Zhou Enlai's conversation with V. K. Krishna Menon, India's representative to the United Nations. Zhou said: "We have never said that we refuse to negotiate with Chiang Kai-shek. On the contrary, we said we are willing to negotiate with him on April 23, during the Bandung Conference. But we did not express this attitude publicly and we will announce this when the appropriate time comes. Cease-fire is the problem between the central PRC government and the Chiang Kai-shek clique. We will undertake direct negotiations with Chiang Kai-shek. But these negotiations are totally different from the international negotiations held between China and the United States." ${ }^{21}$ In addition, China adopted a proactive stance when it announced the release of four American pilots on May 30. Such action demonstrated China's sincere hope forpeaceful and direct talks with the U.S. In addition, this move also raised further concern about the re-detained Americans inside the U.S.

Recognizing that the proposal for the Ten-Nation Meeting could not be achieved, the Soviet Union put forward another proposal to finally

\footnotetext{
18 FRUS, 1955-1957, Vol. 2 (1986), 519-520.

19 Zhou Enlai's conversation with Trevelyan, The Literature Research Center of the CPC Central Committee, Chou En-lai Chronicle, 1949-1976, Vol. 1, (Beijing: The Central Literature Press, 1997), 477.

20 Zhou Enlai, "Report on the Asian-African Conference", People's Daily, May 17, 1955.

21 Zhou Enlai Diplomatic Activities Memorabilia, 1949-1975, (Beijing: The World Knowledge Press, 1993), 111.
} 
launch the Sino-U.S. direct talks. That was the Five-Power Conference. This proposed conference was misunderstood by the Americans immediately. Washington was worried that Moscow could use such a conference as an alternative to the Geneva Summit. Such misunderstanding had existed for a few days until Dulles discussed this with Molotov on May 14,1955 , and took notice of Moscow's real intentions. In Dulles' report toU.S. President Eisenhower that day, he said: "One of Molotov's most significant remarks was that they would propose a five-power conference. This clearly indicated that they would not stipulate that this first four-power conference should itself be a five-power conference."22 From then on, Washington did not worry about the possibility that Moscow could refuse to attend the four-power summit in Geneva. However, there were serious worries that the representative of the Soviet Union would put forward the Five-Power Conference during the Geneva Summit or talk about some other issues related to the direct negotiations between America and Communist China. Some U.S. senators even estimated that the biggest difference during the Geneva Summit might be rooted in Far Eastern problems. ${ }^{23}$

Moscow's proposal of a Five-Power Conference had a substantial impact on Washington's actions around the Geneva Summit. To counter such a proposal, Washington mainly undertook three different actions. The first one was to form the common consensus among the Western allies. For example, on May 31, 1955, Eisenhower wrote to the U.K. Prime Minister Anthony Eden and requested London to maintain a consensus with Washington during the Geneva Summit. ${ }^{24}$ The second action was to prepare the counter proposal for the Summit. Dulles did a lot of preparation for the topics supposed to be discussed during the Summit and reported them back to Eisenhower on June 18: "1. global disarmament, atomic and conventional; 2. unification of Germany; 3. European security; 4. satellite liberation; 5. international Communism; 6. trade". Dulles especially emphasized "satellite liberation" and "trade", since he believed that the former would be strongly opposed by the Soviets, while the latter would be most attractive to them. ${ }^{25}$ The third action was to offer an opportunity of direct talks to the Chinese, and let Moscow's proposal of

22 Department of State, Eisenhower and Marshal Zhukov's meeting in Geneva, July 20, 1955, reproduced in Declassified Documents Reference System (DDRS), Document Number: CK3100270862.

In the Bipartisan Legislative Meeting Pre-Geneva Summit Conference on July 12nd, 1955, Senator Clements stated his concerns about this problem. DDRS, Document Number: CK3100408884.

24 DDRS, Document Number: CK3100436248.

25 DDRS, Document Number: CK3100190453. 
a Five-Power Conference on Far Eastern issues lose any meaning of urgency. On July 8, Eisenhower sent a message to the Indian Prime Minister Nehru and expressed his willingness to hold ambassadorial level talks with Beijing. Then, couple of hours later, in a telegram from Dulles to the U.K. Foreign Minister Harold Macmillan, Dulles said he was "all ready to request your Government as representing US interests at Peiping to make suggestion to Chou En-lai" about the direct talks between the U.S. and PRC. He also urged Macmillan to "get something under way soon, as suggested, so that it will be in the works before we get to Geneva and, as you suggest, will provide the best answer to the Russians". ${ }^{26}$ This action was just fitting into the original intentions of Moscow and Beijing.

Although Washington proposed a direct dialogue with Beijing, it was still not willing to discuss additional issues except the problem of stranded Americans in China, which only made Beijing somewhat disappointed. After some communication with Macmillan and Nehru, Dulles modified his suggestion to Beijing on July 11, which was then orally conveyed to Zhou Enlai by the British charge d'affaires O'Neill two days later. This proposal finally looked like this: "Your and our consular representatives at Geneva have been engaged in intermittent talks during the past year regarding the repatriation of civilians who desire to return to their respective countries. The results have been disappointing to us. It has been suggested that it would aid in settling this matter if these talks were conducted on a more authoritative level, and that this could facilitate further discussion and settlement of certain other practical matters now at issue between the two of us. If you think well of this, we will designate a representative of ambassadorial rank to meet on the above basis with your representative of comparable rank at Geneva on a mutually agreeable date."27 Dulles especially said in his telegram to Macmillan: "The oral message had omitted any expression of reference to the proviso in President's letter to Nehru that 'we could not deal with the rights of third parties in their absence'. We leave this thought implicit in the phrase 'practical matters now at issue between the two of us' in the hope that this treatment will give a lesser impression of rigidity" ${ }^{28}$ In other words, the United States would not like to discuss any issues beyond the problem of repatriation of civilians, particularly the situation regarding Taiwan. The American side only raised the level of the talks between the U.S. and the PRC, but they did not extend the scope of these talks. The Chinese had a clear view about the true attitude of U.S. and they felt

\footnotetext{
26 FRUS, 1955-1957, Vol. 2, 640-641.

27 FRUS, 1955-1957, Vol. 2, 642-643.

28 Ibid., 643.
} 
deeply disappointed about it. In the telegrams from the Chinese Foreign Ministry to its embassies in Warsaw, Geneva and Moscow on July 18, it was said: "Proposal of the U.S. government is the result of various pressures. The U.S. wants to sway the international public opinion in its favor, so that it could solve some practical problems. Even if these problems cannot be solved, it could use it to criticize our delay. The true meaning of such a suggestion is to avoid the mounting pressure on discussing the situation in Taiwan and rejecting Mr. Menon's mediation on this issue. The U.S. also neglected our suggestion of direct contacts between the ambassadors of China and U.S. at the capitals of USSR, UK or India. But if the Sino-American ambassadorial talks suggested by them can only solve some specific issues they care about, then the U.S. may agree to take additional steps to discuss about other issues too. In general, the U.S. is taking a swing policy; it will depend on its real interests to get into talks." ${ }^{29}$

Beijing did not really like the suggestions brought forward by Washington, but also it could not reject them altogether. Therefore, with the Soviet backing, Beijing attempted to change the agenda of these talks and compel the U.S. to give certain concessions during the period of the Geneva Summit.

Cooperation between China and the Soviet Union during the Geneva Summit and the Implementation of Sino-U.S. Ambassadorial Talks

Beijing government did not attend the Geneva Summit, but it had a full exchange and discussion on the Summit with the Soviet Union and it hoped that the Soviet Union would put pressure on the United States to force Washington do give some concessions on the ambassadorial talks. Beijing agreed to talk with Washington at the ambassadorial level when the latter expressed its willingness for such solution through the British charge d'affaires. But China also tried its best to avoid making concessions according to American expectations, thus letting the Soviet Union put forward the topic of the Far East during the Geneva Summit. The Chinese Foreign Ministry then stated: "The ambassadorial talks will aim at solving some practical problems and strengthen the pressure on the United States. Therefore, these talks might be a prelude for high-level negotiations between China and the United States, which could then lessen tensions in the Taiwan Strait. However, these talks cannot hinder the discussion on the Taiwan Strait issue during the Geneva Summit; this should also contribute to the proposal put forward by Soviet Union dur-

29 PRC FMA, Record ID: 111-00014-01. 
ing the Summit. It should also improve the mediating efforts of the USSR, the U.K. and India between the U.S. and China." ${ }^{30}$

In order to achieve this purpose, at first Beijing made a proposal to begin the ambassadorial talks during the session of the Geneva Summit, so that the Chinese side could cooperate with the Soviets during this conference. Thus, if the United States was unwilling to discuss the situation in the Far East and boycotted Soviet proposals, then it should agree to directly talk with China on these issues later on. The proposed date for Sino-US ambassadorial talks by Beijing was July 21, and the Geneva Summit was going to start on July 18 and close on July 23. The Chinese Foreign Ministry instructed its negotiators: "At the first meeting, you should try to ascertain the issues whether the Americans will upgrade the ambassadorial talks to a higher level and whether they are prepared to talk about the issue of easing tensions in the Taiwan Strait area. Therefore, we can coordinate our actions with the Soviet Union in Geneva and let the existing pressure on the U.S. produce some favorable results." ${ }^{31}$ That is to say, because of the previous exchanges of opinion, Beijing was convinced that the Soviet representatives would propose the Far Eastern issue to the Geneva Summit. In order to coordinate with Moscow's action, the copy of Beijing's instructions to its relevant embassies and the English copies of the Sino-U.S. exchanged letters were also sent to Moscow on July 18. ${ }^{32}$ On the same day, People's Daily published an editorial: "Welcome, the Four-Power Summit". The editorial pointed out that "the summit should work to end the 'Cold War', restore mutual trust between countries, and further lessen tensions in the international situation...Therefore, we believe that the Four-Power Summit should discuss the Far Eastern situation, since it is of special importance to the Chinese people and the people of Asia." ${ }^{33}$

The Soviet Union was, indeed, actively preparing to meet China's demands and present the Far Eastern issue at the Geneva Summit. At midnight on July 18, Moscow sent a document to Zhou Enlai whose title was Position of the Soviet Union Delegation at the Geneva Summit. This document conveyed to Beijing the following ideas: "As for Asia and the Far Eastern problems, the Soviet government prepared to propose to the Summit to discuss the following questions: a) restoration of China's legitimate rights in the United Nations, b) the Taiwan issue. The Soviet del-

30 Telegram from the Chinese Foreign Ministry to its embassies in Warsaw, Geneva and Moscow on July 18, PRC FMA, Record ID: 111-00014-01.

31 Ibid.

32 PRC FMA, Record ID: 111-00009-03.

33 People's Daily, July 18, 1955. 
egation will try to make the Taiwan issueone of the most important questions to be raised at this meeting. Because we believe that the solution of this problem would be necessary and imperative to the normalization of the Far Eastern situation in general and to the consolidation of peace in this area... If the U.S. representative would reject to discuss this problem because of the absence of the Chang Kai-shek group, then we would point out that the Chiang Kai-shek group cannot be considered as one party of this international conflict, so it should not be invited to the meeting." ${ }^{34}$ Although the Soviet government generously agreed to cooperate with China, it also had a more realistic assessment of the actual effectiveness of the Geneva summit: "In the current situation, it is difficult to expect that the Summit could obtain a common consensus on the specific pending issues." "Nevertheless, there will be some important personal contacts among the four-power leaders. We will pay more attention to this aspect, and we will try to make the Geneva talks have further contributions to the easing of international tensions." ${ }^{35}$

However, the situation in Geneva was worse than what the Soviet Union or China had expected. First, Washington did not agree to Beijing's proposal on the opening date of the Sino-U.S. ambassadorial talks. On July 15, U.S. Department of State received a message relayed through the British Foreign office that Zhou Enlai had accepted Washington's proposal to conduct further negotiations in Geneva at the ambassadorial level, while the Chinese side also proposed that the first meeting should be held on July 21. The Acting Secretary reported this to Eisenhower and he later expressed great interest in this message but felt it "might create serious complications" if these talks would commence during the meeting of the Heads of Government in Geneva. After further discussions, Eisenhower agreed that the earliest acceptable date would be July $25 .{ }^{36}$ But later, the Assistant Secretary of State for Far Eastern Affairs Walter S. Robertson insisted that the talks with Chinese Communists could not start until the heads of four powers had left Geneva. Therefore, Washington officially asked Beijing to start the first meeting on August $1 .{ }^{37}$ Second, the Far Eastern issue which the Soviet delegation proposed during the Geneva Summit was unanimously opposed by the three Western Powers. On the morning of the Summit's second day, that was July 19, the Plenary Meeting of the Summit passed a resolution which

\footnotetext{
34 PRC FMA, Record ID: 206-00061-07.

35 Ibid.

36 FRUS, 1955-1957, Vol. 2, 655.

37 Tao Wenzhao, The History of Sino-U.S. Relations, 1949-1978, (Shanghai: Shanghai People's Publishing House, 2004), 190.
} 
indicated that the Summit agenda should only include the questions that all four-power heads had interest to discuss or they had discussed on an earlier date. There were four issues that could be included into the conference agenda: a) Germany; b) European security; c) disarmament; and d) expansion of contacts between the East and the West. ${ }^{38}$ From then until the closing meeting on July 23 in the afternoon, the Soviet proposal about the Far East was never discussed during the formal sessions of the Summit. In fact, there were no other specific agreements reached by this Summit, besides the "Instructions from Heads of Four Powers to their Foreign Ministers". The four heads of state could only promise to hold a meeting of Foreign Ministers in order to continue further consultations regarding the above mentioned issues. However, the Soviet Union vigorously propagated the success of the Geneva Summit and it pointed out that this summit had set up a base for "sincere contacts and mutual respect" among the heads of these four powers. Moscow also believed that the success of the Geneva Conference owed much to "the spirit of cooperation and mutual understanding". ${ }^{39}$

Under these new conditions, China reluctantly adopted new strategies to continue cooperation with the Soviet Union. First, Beijing government pointed out to the unreasonable conditions put forward by Washington in its proposal on the ambassadorial talks, so the Chinese side consciously delayed its answer to American demands concerning the date of the meeting. At the same time, Moscow pretended that it knew nothing about the Sino-U.S. direct talks and continued to exert pressure on the West to discuss the situation in the Far East in international forums. On July 18, Zhou Enlai received another American message through consul D. W. O'Neill. The message was put together in an identical way: "As a result of communication between Peiping and Washington through the diplomatic channels of the United Kingdom, it has been agreed that the talks held last year between consular representatives of both sides at Geneva should be resumed at the ambassadorial level in order to assist in settling matters concerning the repatriation of civilians who desire to return to their respective countries and to facilitate further discussions and settlement of certain other practical matters now at issue between both sides. The first meeting of ambassadorial representatives of both sides will take place on August 1, 1955, in Geneva". After Zhou Enlai read this message, he changed his calm attitude and launched some fiery criticisms of the U.S. message : "Why did they use the word 'Peiping'? China

\footnotetext{
38 The People's Daily, July 21, 1955.

39 Bulganin, "Report on the Results of the Four Powers Geneva Summit, August 4, 1955, the Third Session of the USSR Supreme Soviet", The People's Daily, August 6, 1955.
} 
has an old saying - 'Name has to follow the owner.' Americans are always unreasonable. But you, our British friend, as a matter of courtesy, should have declined even to transmit such a proposal." In addition, Zhou Enlai expressed his regret that the Americans had refused to consider July 21 as the date for the first ambassadorial talks. He also did not give any formal reply to the U.S. proposal on the August 1 timetable. His harsh attitude not only frightened O'Neill, but also shattered American and British expectations. Thus, the Americans had to primarily hold consultations on China's stance with the heads of other powers meeting in Geneva, particularly with the Soviet delegation. For example, Dulles discussed a number of matters about China with Marshal Bulganin on July 21, 1955, in Geneva. During this meeting, Bulganin suggested to his American counterparts to "get in touch with the Chinese People's Government" as if he knew nothing about the previous contacts between Beijing and Washington through British diplomatic channels. And he also pretended not to understand the true meaning of the word "Peiping" to Chinese Communist leaders. However, Bulganin did pose a question with Dulles that raised most concern in Beijing, "whether you will just discuss about nationals staying on both sides or you will also broaden the scope of your talks". ${ }^{40}$ On July 22, Dulles recalled that the "Chicoms have not yet agreed to the Geneva meeting" and he was concerned that "they have changed their mind". Macmillan's words further disturbed Dulles. Macmillan thought Beijing's acceptance might "have been to get to Geneva when the Conference was in session, and when the date was put after its adjournment, they might have decided not to go ahead". ${ }^{41}$ Washington did not receive Beijing government's reply on the text of press announcement until July 23, the very last day of the Geneva Summit. American officials only found out that there were just two words which the Chinese had altered. It was "Peking" instead of "Peiping" and "conducted" instead of "resumed". ${ }^{42}$ After a bit of haggling, Beijing and Washington finally released a press announcement on the coming Sino-U.S. ambassadorial talks on July 25.

Second, the Chinese government adjusted the negotiation tactics for the ambassadorial talks and attempted to make the talks more suitable to the new international situation. On the same day as the press announcement on Sino-U.S. ambassadorial talks was released, Chinese Foreign Ministry set up the Geneva Talks Steering Group which was directed at researching the background of the Sino-U.S. negotiations and

\footnotetext{
40 FRUS, 1955-1957, Vol. 2, 670-671.

41 Ibid., 672-673.

42 Ibid., 675.
} 
shaping the proposals for the Chinese negotiation's plans. This group was headed by Zhang Hanfu who was one of the Vice Foreign Ministers. Its main members included Qiao Guanhua, He Fang, all famous Chinese diplomats, as well as Ling Yun who was one of the Vice Ministers of the Chinese Public Security Ministry. ${ }^{43}$ On July 26, Chinese Foreign Ministry handed this report to Zhou Enlai. The report had the following title "The Supplement Request for Instructions for the Geneva Talks": "The original program was formed under the assumption that the Sino-U.S. ambassadorial talks would begin on July 21 . So it had taken into account some steps to coordinate actions with the Soviet delegation at the Geneva Summit. But now, the four-power meeting had ended, thus these specific instructions were not necessary any more. So we have to adjust our tactics as these talks will start on August 1. Our new plan should aim at increasing the pressure on the United States, trying to solve some practical problems through the talks, preparing for higher level talks between China and U.S. which can then ease the tensions in the Taiwan Strait area. However, Sino-U.S. ambassadorial talks cannot hinder mediation efforts which are pursued by the Soviet Union, Britain and India. We should ensure that these talks be conducive to improving such mediation efforts". ${ }^{4}$ In addition, this report proposed some concrete steps to be taken during the first meeting: "We should still be ready to propose two following issues during the first proposed meeting of the talks: problem of the repatriation of their nationals. At Bandung China recommended to sit down and make an effort to ease the tensions in the Taiwan Strait as a preparatory work for the negotiations, but since the four-power meeting has ended, some concrete steps should be made accordingly. For example, if the representatives of the United States claim not to have the authority to discuss the second issue, we should still tell that to the press, but not immediately after the meeting on the same day". 45

Third, the Chinese government adjusted its attitude towards the outside world under the "Geneva spirit" which was also readily advocated by the Soviet Union. Beijing fully endorsed the propaganda of the "Geneva spirit" and it also hoped to seize the opportunity to draw a new pattern for China's diplomacy in a relatively friendly international atmosphere. On July 30, 1955, Zhou Enlai gave a speech at the second meeting of the First Session of the Chinese People's Congress on the topic of "The Current International Situation and Our Foreign Policy". He stated: "The USSR, the U.S., the UK and France held their first summit after the Second

\footnotetext{
43 Biography of Zhang Hanfu, (Beijing: The World Knowledge Press, 2003), 306-307.

44 PRC FMA, Record ID: 111-00009-04.

45 PRC FMA, Record ID: 111-00009-04.
} 
World War in Geneva this month... The summit will further promote relaxation of international tensions, rebuild the necessary trusts between the great powers, and it will also inspire the peace-loving peoples and countries all over the world to make greater efforts for the consolidation of lasting peace". As for the coming Sino-U.S. ambassadorial talks, Zhou Enlai also said: "As long as both sides express sincerity during consultations, these talks will promote the reconciliation between China and the U.S. First of all, the issue of civilians from both sides finally returning home should be solved in a reasonable way... But we also expect that these talks will produce other effects as both sides announced in their press statement: facilitating further discussions and settlement of certain other practical matters now at issue between both sides" ${ }^{\prime 6}$ Before dawn on July 31, the Chinese Foreign Ministry gave instructions to the Chinese representatives present at the Sino-U.S. talks and it also proposed a fundamentally new tactic during this first meeting: "At the beginning of tomorrow's meeting, you can suddenly announce that we have released 11 illegal U.S. military personnel a short time ago. This move will remove any complaints coming from the U.S. representatives about our insincerity and it will put additional pressure on them to make the next move. Then, you should seek solutions to some specific issues at the meeting, as if you were making preparations for the high-level negotiations between China and the U.S. Our concessions disguised under this initiative will also compel the U.S. to become more isolated and passive". ${ }^{7}$ Later that day, Zhou also met with the Soviet charge d'affaires in Beijing and passed on a memorandum to him: "The First Meeting of the SinoU.S. Ambassadorial Talks in Geneva on August 1". This memorandum presented in details China's stance and strategy concerning this meeting. ${ }^{48}$ This meant that the continuous close cooperation between Beijing and Moscow was carried on.

On August 1, 1955, the first meeting of the Sino-U.S. ambassadorial talks was finally held in Geneva. China gave full recognition of Soviet Union's assistance during the process of preparing the ambassadorial talks. People's Daily published an editorial dedicated to the Soviet Union's contributions in "ending the Cold War". The editorial stated: "The Chinese people warmly welcome the Soviet government's initiative to support China which is doing its best to ease the situation in Asia and the Far Eastern area. The Soviet government has always been maintaining

\footnotetext{
$46 \quad$ People's Daily, July 31, 1955.

47 These instructions were sent out at 3am, July 31, 1955. PRC FMA, Record ID: 11100014-03.

48 Zhou Enlai Diplomatic Activities Memorabilia, 1949-1975, 121-122.
} 
peace in Asia. Its efforts have already exercised an important role in easing the situation in Asia and it will always play a significant role in this area. After the end of the Geneva four-power Summit, it is quite possible that the spirit of mutual understanding and cooperation, which was embodied in the Summit, will relax the explosive situation in the Far East. Therefore, the Sino-U.S. ambassadorial talks, which started on August 1, are held under favorable circumstances." In addition, the editorial said: "If both sides of Geneva talks follow the 'Geneva spirit', whose core concept is 'replacingforce by negotiations' and taking a conciliatory attitude towards negotiations, then these talks could present a favorable way to solve problems in Asia and the Far Eastern area." ${ }^{49}$

Indeed, in the process of the four-power Summit in Geneva, the Soviet Union closely cooperated with China on Far Eastern issues. First of all, Soviet representatives had been trying to discuss the Far Eastern problems during some of the formal meetings of the Summit. Second, when they had to give up on this issue at the formal forums in Geneva, they had repeatedly discussed Far Eastern problems and the China problem on some personal occasions. Soviet initiative did put more pressure on the United States, while the concrete developments of the international situation made the Americans attach more importance to the China problem. Therefore, the Sino-U.S. ambassadorial level talks took place in Geneva shortly after the Summit had ended.

\section{Conclusion: The Sino-Soviet Relations Embodied in the Implementation Process of Sino-US talks}

From the five-power Geneva Conference in 1954 to the four-power Geneva Summit in 1955, Beijing adhered to the "negotiations rather than force" rule, which was at the core of the "Geneva spirit", and actively pursued the implementation of ambassadorial level talks with the United States in a more relaxed international atmosphere after the Korean War, acquiring generous assistance from the Soviet Union. This process reflected the high level of Sino-Soviet cooperation, solidarity and co-ordination in international relations. However, there were also certain inconsistencies, due to their particular interests and some small differences in their stances. But as the two main members of the Socialist Camp of the world, both China and Soviet Union set their goals on their overall objectives, ignoring any differences between them.

49 "Keeping Work For Ending the Cold War", People's Daily, August 6, 1955. 
First, the close coordination between the governments of the PRC and the USSR in promoting Sino-U. S. direct talks reflected some of the key features characteristic for the golden years of Sino-Soviet relations, also known as the "honeymoon period" of Sino-Soviet relations. The Soviet Union never forgot to assist China's international position during that time. During the Geneva Summit, although their proposal on discussing the Far Eastern issue was rejected by the three western powers, the head of the Soviet delegation still emphasized in his closing statement: "There is one matter that made us, the Soviet delegation, feel regret. Asia and the Far Eastern area problems have not been given due attention during this summit. Thus, some urgent problems cannot be delayed any more, such as the recognition of the People's Republic of China as the only lawful representative of China in the United Nations, recognition that the Chinese people have indisputable rights concerning the Taiwan issue, realization of the Geneva Agreement on Indochina, and so on. These problems have to be resolved in accordance with the interests of the people of Asia and the Far East, as well as in accordance with the international peace and security." ${ }^{\prime 50}$ Besides this official statement, Soviet representatives used this opportunity provided by the Geneva Summit to discuss with their American counterparts all outstanding issues connected with China. For example, the Soviet Minister of Defense, Marshal Georgy Zhukov, utilized his close personal relationship with Eisenhower in order to discuss with him the China issue a couple of times. On July 20, Zhukov had lunch with Eisenhower and he told the American President that he had thought the settlement of the Chinese problem had "great importance for the relaxation of tensions". "There was, first of all, the question of China's membership in the UN", Zhukov reminded Eisenhower, indicating that PRC's absence from that international organization meant that "a nation of 600 million people was not represented in this organization." "Then, of course, there was the question of Taiwan itself", added the Soviet Marshal. He felt that the delay in settling these issues was "not advantageous even to the United States". ${ }^{11}$ On July 23, Zhukov made another reference to China during his next meeting with the U.S. President. He said that he believed that the Chinese had no intention to resort to armed force, since "they have been waiting patiently for settlement of these matters and if some hope could be given to them there was no doubt that they would continue to wait with patience." Therefore, Zhukov felt that the initiation of direct talks between the United States

$50 \quad$ People's Daily, July 25, 1955.

51 DDRS, Document Number: CK3100207051- CK3100207064. 
and China "would give such hope". ${ }^{2}$ In short, the Soviets utilized the diplomatic language which the Chinese side also used and they took some steps which China had also taken.

Chinese diplomats had a more intuitive understanding of the developments taking place inside the Sino-Soviet friendship during this period. For example, in one of the reports which was sent by the Chinese Embassy in Moscow to the Chinese Foreign Ministry at the end of May, 1955, Chinese diplomats in the USSR said: "During the past six months, due to the relaxation of the international situation and the development of the Sino-Soviet friendship, there have been more and more friendly activities between our two countries every single day. The Soviets have taken a number of new practices which never happened in the past while communicating with us." These "new practices" included: "The Soviet Foreign Ministry was extending warmer welcomes and farewells to different Chinese delegations which were only passing thorough the Soviet Union; the Soviet Foreign Ministry was inviting Chinese diplomats to attend more and more friendly activities, some of them even going "beyond the formal diplomatic routine". ${ }^{33}$ By the end of 1955, the Chinese embassy in Moscow reported again: "Over the past year, the Sino-Soviet relations have been closer; all kinds of personal exchanges are very frequent now". ${ }^{54}$ At that time, Chinese citizens travelling to Western countries having no diplomatic relations with the PRC got their visas through the Chinese Embassy in Moscow, while Western citizens travelling to China had to get their visas through their own embassies in the Soviet Union. In 1955, the Beijing governmentset up a specific information-exchange station in Moscow which was aiming at contacting embassies of Western countries in Moscow. If the Chinese government was planning some important diplomatic initiatives, it would always tell Moscow in advance, conducting consultations with Soviet officials and seeking for their advice. Moscow was also willing to share sensitive information with Beijing.

However, even during the Golden Period of the Sino-Soviet relationship, certain differences still existed between the two communist powers. As mentioned above, in order to fight against the Soviet proposal of a Five-Power Conference to solve the Far Eastern problems, the United States prepared six corresponding proposals to be discussed at the Geneva Summit. One of their intentions was to compel the Soviets to give up on their Far Eastern proposal in exchange for U.S. abandonment of the proposal concerning the communist satellites. A passage of

\footnotetext{
52 DDRS, Document Number: CK3100207065- CK3100207069.

53 PRC FMA, Record ID: 117-00456-05.

54 PRC FMA, Record ID: 118-00558-02.
} 
Bulganin's statement could reflect such an exchange. In his report on the Geneva Summit at the Third Session of the Supreme Soviet of the USSR: "Unfortunately, the proposal raised by us that the meeting should also discuss Asian and Far Eastern issues was not accepted, even though these issues were obviously pressing due to the real situation in this area. But, of course, the Soviet delegation could also not agree to discuss the issues concerning Eastern European countries and international communism'. We had to point out that if such issues were discussed at this summit, it meant that we would interfere into the domestic affairs of East European countries." ${ }^{\prime 5}$ So, maybe we can speculate: the issues about Eastern European countries and "international communism" were more important to the Soviet Union than the issues concerning Asia and the Far East, even though the latter had been repeatedly stressed by the Chinese. This was a kind of sacrifice of Beijing's interests, China's full coordination of its policies with Moscow notwithstanding. At that time, China desperately wanted to ensure that the Sino-U.S. ambassadorial talks take place during the Four-Power Summit.

On the other hand, the Chinese did adhere to a basic rule in diplomatic practices - an "independent foreign policy". This meant that if Soviets touched upon some issues relating to China's national interests, the Chinese side would be uncompromising and stick to its own opinion. In Chinese political terminology, Soviets touched upon some "soft nails". For example, on December 12, 1954, Soviet Ambassador to China Pavel Yudin conveyed to Zhou Enlai some of the reflections made by British diplomats on the issue of the trial of 13 U.S. spies who had been arrested in China. It was obvious that the Soviets wanted to mediate this problem. On December 16, Zhou Enlai gave an answer to Yudin in which he said: "This is our domestic affair and we refuse any interference coming from any country". Yudin decided to press on, so he questioned Zhou why would China then welcome the Secretary General of the UN Hammarskjold to come to China and discuss this issue. Zhou replied: "If we reject him (Hammarskjold), we will fall into a passive situation, and they (Americans) will continue to take actions through neutral countries in Asia. For example, Ceylon would certainly put forward this question at the Colombo Meeting. That will be unfavorable for us and will affect our attendance of the Asian-African Conference next year." ${ }^{\prime 56}$ Moscow was disappointed with Beijing's refusal. Even through some of the personal contacts with the Americans, some Soviet officials could not

\footnotetext{
55 Bulganin, "Report on the Results of the Four Power Geneva Summit, August 4, 1955, the Third Session of the USSR Supreme Soviet", The People's Daily, August 6, 1955.

Zhou Enlai Diplomatic Activities Memorabilia, 1949-1975, 95.
} 
hide their disaffection with some of the Chinese policies. In an informal meeting, when Dulles mentioned that there had been a lot of MIGs in China, Bulganin answered: "We are not giving them MIGs anymore. We find the more we give them, the more they want." ${ }^{57}$ Although we cannot exclude that Bulganin's statement was a deliberate gesture towards the Americans, it could also be a kind of real reflection of the Soviet disenchantment with China's impatience.

The US had never forgotten to "drive a wedge" between the USSR and the PRC since 1949. Washington would never give up this aim, even when it had direct contacts with the PRC. In the mid-1950s, with the rise of China's international status, the independence of initiative in Chinese diplomacy was also increasing. But the intelligence community of the United States found, "While this Soviet acknowledgment of China's international position has given rise to some speculation about future differences and difficulties between the two powers, as of year's end there were virtually no significant cracks visible here in the monolithic facade of relations between the two." ${ }^{58}$ Therefore, while there were some unharmonious voices in Sino-Soviet relations in 1955,the main stream was still true friendship.

All in all, the close relationship between China and the Soviet Union could be also seen in the propaganda of following words - "Geneva spirit", which embodied the same goals both countries shared in their efforts at easing international tension. Both of these countries needed firm guarantees of peace and stability in order to achieve their domestic reconstruction. After Stalin's death, the Soviet Unionbegan gradual changes as to pull their domestic system away from Stalinist demands. Moscow had to pay more attention to increasing domestic production and improving people's living standard, while China had to do the same, but the situation was far more pressing due to the consequences of the Korean War. Beijing made it clear that the main purpose of the so-called "independent and peaceful foreign policy" was "to construct our country into a prosperous, powerful and wealthy socialist country". ${ }^{59}$ In addition, China had basically completed the domestic social changes, while the Chinese Communists had consolidated their regime by the end of 1954 . Therefore, Zhou Enlai announced with much self-confidence: "Now, we

$57 \quad$ FRUS, 1955-1957, Vol. 2, 670-671.

58 American Consulate General, Hong Kong, DESP, No. 1612, Analysis of Sino-Soviet Relations in 1954, March 28, 1955, MF2523166-0105, Main Library of the University of Hong Kong.

59 Zhou Enlai,"Current International Situation and Our Foreign Policy - Speech at the Second Session of the First Session of the National People's Congress of the PRC", People's Daily, July 31, 1955. 
have gone through a preliminary reorganization, 'our house' has been cleaned up, so we can 'invite some guests to come home' now." ${ }^{10}$ From the Geneva Conference in 1954 to the Bandung Conference and the SinoU.S. ambassadorial talks in 1955, China had gradually exercised a much different role in its international entanglements. Full-time propaganda of the "Geneva spirit" also took place during this period. However, by the late 1950s, some of the more radical reforms also occurred in China; the Great Leap Forward was a particularly famous one. Chinese diplomatic policies had by then turned to the "left" and communist revolution had become a paramount goal by then. Negotiations and relaxation of tensions were not considered as a favorable orientation of China's international strategy. Propaganda of the "Geneva spirit" also cooled down. These obvious changes could be also observed through the data published in the People's Daily. In 1955, the number of articles and reports which praised the "Geneva spirit" and seen it as the core spirit of country's international activities was 111. That number was 43 in 1956, 8 in 1957, 0 in 1958, and only 2 in 1959. After 1960, People's Daily rarely mentioned the "Geneva spirit". But there was one exception. In 1967, there was an article in the People's Daily which mentioned this expression and it was titled The Counterrevolutionary Face of Sholokhov. It said the following: "From the 'Geneva Spirit' to the 'Moscow Spirit', Sholokhov and Khrushchev, one master and one servant, echoed each other, walked on a more and more despicable path of betraying Communism. They have become loyal lackeys of imperialism". The meaning of the "Geneva spirit" had totally changed. The evolution of this term in China can also reflect the specific path of development of the Sino-Soviet relationship, from friends to enemies.

Although there were no definite and unified conclusions about the historical role of the Sino-U.S. ambassadorial talks, one could not deny two things: first, it was of diplomatic importance, since it was an initiation of long-term contacts between the two sides that ultimately led to China's recognition by Washington in the 1970s. Second, these talks also proved to be a special diplomatic channel between the two sides to discuss some of the outstanding issues and try to diffuse explosive situations. Therefore, the realization of these ambassadorial talks was a diplomatic victory for Beijing and this victory could never been achieved without the close cooperation and coordination between China and the Soviet Union.

60 Zhou Enlai Chronicle, 1949-1976, Vol. 1, 420. 


\section{Sources and Literature}

\section{Archives and Databases}

- Chinese Foreign Ministry Archives (PRC FMA)

- Foreign Relations of the United States (FRUS). 1952-1954, Vol. 14. Washington: United States Government Printing Office, 1985.

- FRUS. 1955-1957, Vol. 2 (1986)

- Declassified Documents Reference System (DDRS)

- American Consulate General. Hong Kong, DESP. No. 1612, Analysis of Sino-Soviet Relations in 1954, March 28, 1955, MF2523166-0105, Main Library of the University of Hong Kong.

\section{Newspapers}

- People’s Daily

\section{Memoirs, Biography and Chronicle}

- The Diplomatic History Research Office of the PRC Ministry of Foreign Affairs. Zhou Enlai Diplomatic Activities Memorabilia, 19491975. Beijing: The World Knowledge Press, 1993.

- The Literature Research Center of the CPC Central Committee. Zhou Enlai Chronicle, 1949-1976, Vol. 1. Beijing: The Central Literature Press, 1997.

- Biography of Zhang Hanfu. Beijing: The World Knowledge Press, 2003.

\section{Books and Articles}

- Young Kenneth T. Negotiating with the Chinese Communists: The United States Experience, 1953-1957. New York: McGraw-Hill, 1968.

- Harding Harry and Ming Yuan. Sino-American Relations, 1945-1955: A Joint Reassessment of a Critical Decade. Wilmington, Delaware: Scholarly Resources, 1989.

- Soman Appu K. Double-Edged Sword: Nuclear Diplomacy in Unequal Conflicts: The United States and China, 1950-1958. Praeger, 2000.

- Beam Jacob. Multiple Experience: An American Ambassador's Unique Perspective on East-West Issues. New York: W.W. Norton 1978.

- Johnson Alexis. The Right Hand of Power: The Memoirs of an American Diplomacy. Englewood Cliffs, N.J.: Prentice Hall, Inc., 1984. 
- The Diplomatic History of PRC, 1949-1956, ed. by Pei Jianzhang. Beijing: The World Knowledge Press, 1998.

- The Diplomatic History of PRC, 1957-1969, ed. by Wang Taiping. Beijing: The World Knowledge Press,1998.

- Wang Bingnan. Retrospect of the 9-year Talks between China and the US. Beijing: The World Knowledge Press, 1985.

- Goldstein Steven M. "Dialogue of the Deaf? The Sino-American Ambassadorial-level Talks, 1955-1970". Re-examining the Cold War: US-China Diplomacy, 1954-1973, Collectedin Robert Ross\& Jiang Changbineds, 200-237. Cambridge: Harvard University Press, 2001.

- Yafeng Xia. "Negotiating at Cross-Purposes: Sino-American Ambassadorial Talks,1961-1968". Diplomacy and Statecraft, 16:2, June 2005, 297-329.

- Yafeng Xia. Negotiating with the Enemy: U.S.-China Talks during the Cold War, 1949-1972. Bloomington, IN: Indiana University Press, 2006.

- Dayong Niu. Warsaw Ambassadorial-Level Talks between China and the United States, 1961-1963, Historiography at the Peking University, 2000.

- Zhang Baijia and Jia Qingguo. The Steering Wheel, Shock Absorber and Surveying Instrument in Antagonism: Sino-American Ambassadorial Talks Seen from the Chinese Perspective, Contemporary China History Studies, Vol. 1, 2000.

- Tao Wenzhao. The History of Sino-US Relations, 1949-1978. Shanghai: Shanghai People's Publishing House, 2004. 


\title{
Резиме
}

\section{Кинеско-амерички амбасадорски разговори и самит у Женеви 1955. године: Дипломатска постигнућа НР Кине остварена уз помоћ Совјетског Савеза}

\begin{abstract}
Апстракт: У овом чланку ауторка анализира везе између Самита четири велике силе у Женеви и спровођења у дело кинеско-америчких амбасадорских разговора. После исцрпне анализе, она закључује да је процес остваривања амбасадорских разговора одражавао висок ниво сарадње и узајамне подршке Кине и Совјетског Савеза средином 50-их година. Овај период је стога назван „меденим месецом“ у односима између ове две земље. Међутим, током ових златних година неке од првих пукотина у њиховом односу почеле су да избијају на површину.
\end{abstract}

кључне речи: Самит у Женеви, дух Женеве, кинеско-амерички амбасадорски разговори, кинеско-совјетски односи

Овај чланак користи тек отворена документа из Архива Министарства иностраних послова НР Кине, друге кинеске архивске материјале, као и нека новодоступна документа архива Сједињених Држава, како би изнова истражио процес спровођења кинеско-америчких амбасадорских разговора и анализирао везе између ових разговора и Самита четири велике силе у Женеви 1955, при чему је посебна пажња посвећена сарадњи и узајамној помоћи Кине и Совјетског Савеза. Насупрот скорашњим истраживањима, у чланаку се износи теза да је Совјетски Савез играо много важнију улогу у процесу спровођења кинеско-америчких амбасадорских разговора. Овај процес је изванредан пример „меденог месеца“ кинеско-совјетских односа средином 50-их година. Исто тако, чланак разоткрива и прве пукотине у кинеско-совјетском односу током златних година њиховог савеза. 